\title{
Research of the economic risk factors of the functioning of the Ukrainian transport system
}

\author{
Nataliia Bogdan ${ }^{1 *}$, Sergii Pogasiy ${ }^{1}$, Iryna Pysareva ${ }^{1}$ and Iuliia Krasnokutska ${ }^{1}$ \\ ${ }^{1}$ O.M. Beketov National University of Urban Economy in Kharkiv, 17, Marshal Bazhanov Street, \\ Kharkiv, 61002, Ukraine.
}

\begin{abstract}
The purpose of this article is to research and to evaluate the risk factors of the transport system of Ukraine. The article examines the state of the transport system of Ukraine. The classification of specific risks of the transport system has been developed in two areas: the nature of occurrence and in relation to the transport system. The conceptual model of comprehensive research of the factors of economic risk has been proposed. It includes 4 modules. The approaches to the identification of the factors and indicators for assessing the economic risks of transport systems at the national and regional levels have been formed. In the result the comprehensive evaluation of the risk factors of regional transport system of Ukraine has been carried out. Identification of risks at the national and regional transport system is necessary for the effective strategy of the industry development through quantitative risk analysis which enables to give a real assessment of their own resources and capabilities in relation to the state (and needs) of the external environment. The rational choice of the strategies from a variety of options should be made on this basis.
\end{abstract}

\section{Introduction}

The strategy of the transport systems development at national and regional levels which are being established currently in most cases do not consider the economic risks emerging at all levels of management. The complexity, the vagueness and differentiation of the sources of risk manifested in the transport systems makes it difficult to assess the integral level of economic risk, which in turn leads to a decrease in the effectiveness of management decisions in the industry.

Recently the impact of economic risks on transport system at meso and micro levels has been reinforced. The volume and quality characteristics of transport, its infrastructure do not allow to solve the problem of the economy effectively. This requires a substantial restructuring of the transport sector which involves additional risks.

The problems of the development of transport system was considered in the researches of Ukrainian scientists: K. Andriushchenko [1], M. Bidniak [2], O. Boyko [3], P. Gorbachiov [4] A. Gorev [5], V. Dykan [6], O. Kravchenko [7], O. Pikulic [8], I. Rogozian [9] etc. The most

\footnotetext{
${ }^{1 *}$ Corresponding author: bogdan.nataliya.67@gmail.com
} 
famous foreign researchers of transport system are A. Balducci, L. Boelens, J. Hillier [10], P. Kellermann, A. Otto [11].

Despite the large number of research papers on transport issues, problems of identification, assessment and minimization of risks are not sufficiently considered.

The research papers on the risks of transport system functioning are not enough. Further research is required, in particular, the analysis of risk factors based on industry and socioeconomic characteristics of the development of territories, their classification, quantification, degree of influence of risk factors on the competitive position of industrial complex and the formation of its development strategy and a number of others are not covered in modern scientific papers.

Insufficient development of theoretical and practical problems of the functioning of transport systems in risk conditions determined the choice of research topic, its aims and objectives, and logic of research. Thus, the aim of this paper is to study and to evaluate the risk factors of the transport system of Ukraine.

\section{Methods}

The system of indicators for assessing external and internal risk factors of a transport system has been established by the authors. These indicators were evaluated using the method of expert assessments. The integrated risk assessment of regional transport complexes of Ukraine is calculated.

\section{Results and discussion}

The transport sector includes all participants of transportation market. Risks in the transport sector involve the discrepancy between the actual parameters of the market and its expected values [12]. These parameters include the degree of concentration of capital, elasticity and other characteristics of supply and demand in the industry, inflation rates and stability of rates, the balance of the market, the deterioration of the material and technical base of the industry, aging rolling stock, the quality of the labor force and employment in the industry, the instability of tax policy, the liquidity and solvency of the motor transportation enterprises (organizations), reduction of investment attractiveness of the industry, imperfect legal support of the carriers.

The situation in the transport system depends on the general socio-economic situation in the country and the region.

At the present stage of Ukraine's economy development transport plays a crucial role in ensuring the economic growth and social development of the country. At the end of 2017, Ukrainian transport sector takes $6.4 \%$ in the sectoral structure of GDP. This rating has decreased significantly since 2010 - more than $37 \%$ which proves the efficiency reduction transport functioning

Analyzing the socio-economic development of Ukraine by the macroeconomic indicator of gross domestic product (GDP), it should be noted a steady tendency of growth and change of this indicator during 2010-2018: its value increased almost 3 times. However, a significant impact on the growth rate of economic development had a global financial crisis, which increased the level of economic risks. The domestic risks took place starting in 2014, when there was a decline in all sectors of the economy.

Economic risk in the transport sector is sectoral, national and regional in nature. It represents the probability of deviations of results of the activity of entities of transport system from the predicted values due to changes in the economic situation in the transport sector and in the socio-economic situation of the country.

The following risks for transport enterprises and the industry in the whole can be 
defined: macroeconomic, geopolitical, operational, social, technological, environmental.

The authors propose a classification of specific risks of the transport complex (Fig. 1).

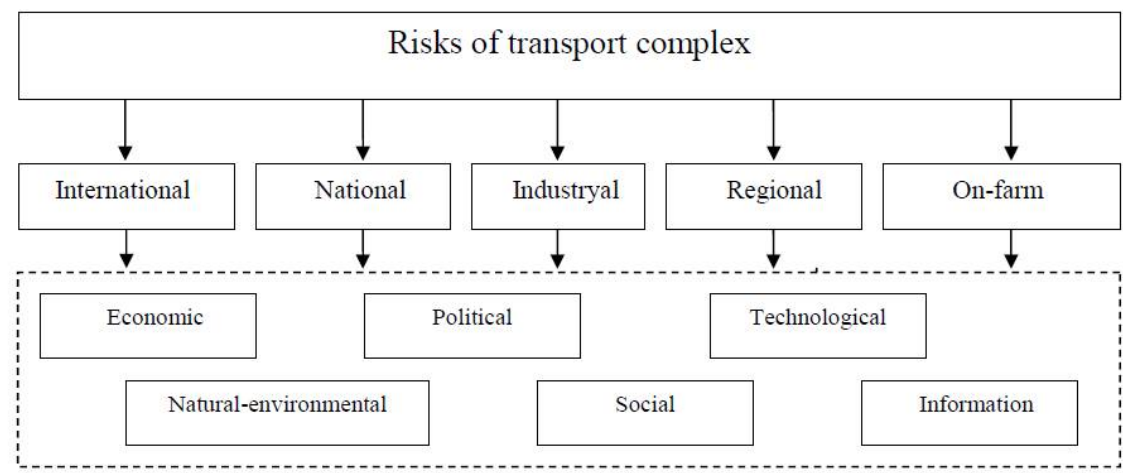

Fig. 1. Risk classification of transport system

Thus, it is possible to determine the economic risk of the transport system as the probability of deviations of the results of its entities from the predicted values due to changes in the economic situation in the transport sector and in the socio-economic situation of the country or region.

Analyzing the economic risk of the transport sector including the following types: general economic, financial, investment and innovation, socio-demographic, market, resource, logistics, production, management. Each of these sources of risks include general economic risk complex and requires analysis and evaluation [13].

Authors systematized the risk factors of the transport system and classified them according to the following criteria:

- the environment of occurrence (external, generated by the conditions of macro - and mezzo level of transport system of the region);

- according to the economic nature of occurrence.

Thus, the approaches to the identification of factors and indicators for assessing the economic risk of transport systems at the national and regional levels have been formed.

Considering the indicators for risk assessment of the transport system, the individual and integrated risk analyses of regional transport of Ukraine was undertaken [14].

Table 1. Weighting factors of the group risk factors regional transport.

\begin{tabular}{|c|c|c|c|}
\hline Group & Group weights & Group & Group weights \\
\hline \multicolumn{2}{|c|}{ External risk factors } & \multicolumn{2}{c|}{ Internal risk factors } \\
\hline 1 & 0.09 & 1 & 0.045 \\
\hline 2 & 0.04 & 2 & 0.045 \\
\hline 3 & 0.05 & 3 & 0.05 \\
\hline 4 & 0.035 & 4 & 0.045 \\
\hline 5 & 0.045 & 5 & 0.06 \\
\hline 6 & 0.035 & 6 & 0.055 \\
\hline 7 & 0.055 & 7 & 0.055 \\
\hline 8 & 0.04 & 9 & 0.05 \\
\hline 9 & - & 9 & 0.04 \\
\hline
\end{tabular}

The data of the official website of the Ministry of infrastructure of Ukraine, materials of RA “Expert-Rating”, "Transport' journal was applied for the evaluation [15, 16]. 
The experts from RA "Expert rating" (7 experts) and experts in the field of transport infrastructure, the authors of "Transport" journal (8 experts) were involved for expert assessment of risk factors of regional transport complexes, and for determining the weights of groups of risk factors (table. 1).

Based on statistical data, the scores for each risk factor for each region were given to experts, on this base the integrated assessment of regional transport were calculated. The results of the evaluation are presented in table. 2.

The evaluation of the risk factors of regional transport of Ukraine has been conducted in the result of the research.

The accounting system and the assessment of risk factors of the transport complex must be built into the management system, due to the high-risk nature of the transport industry [17].

Table 2. The results of evaluation of the risk factor of regional transport of Ukraine in 2017.

\begin{tabular}{|c|c|c|}
\hline \multirow{2}{*}{ Region } & \multicolumn{2}{|c|}{2017} \\
\hline & $I R$ & Rank of the region \\
\hline Vinnytsya region & 0.435 & 13 \\
\hline Volyn region & 0.282 & 19 \\
\hline Dnipropetrovsk region & 0.988 & 5 \\
\hline Donetsk region & 0.818 & 16 \\
\hline Zhytomyr region & 0.349 & 11 \\
\hline Zakarpattya region & 0.249 & 20 \\
\hline Zaporizhzhya region & 0.971 & 5 \\
\hline Ivano-Frankivsk region & 0.395 & 12 \\
\hline Kyiv region & 0.852 & 3 \\
\hline Kirovograd region & 0.382 & 10 \\
\hline Lugansk region & 0.579 & 18 \\
\hline Lviv region & 0.484 & 4 \\
\hline Mykolayiv region & 0.701 & 7 \\
\hline Odessa region & 0.767 & 6 \\
\hline Poltava region & 0.907 & 7 \\
\hline Rivne region & 0.322 & 17 \\
\hline Sumy region & 0.399 & 8 \\
\hline Ternopil region & 0.191 & 21 \\
\hline Kharkiv region & 0.727 & 2 \\
\hline Kherson region & 0.301 & 14 \\
\hline Khmelnytsky region & 0.371 & 15 \\
\hline Cherkasy region & 0.505 & 9 \\
\hline Chernivtsi region & 0.188 & 22 \\
\hline Chernigiv region & 0.335 & 16 \\
\hline Kyiv & 0.991 & 1 \\
\hline
\end{tabular}

The high level of risk in national and regional transport complexes requires the development of appropriate strategies of the activities for creating the competitive advantages through formal procedures, which are defined in stages and for application the techniques of analysis and modeling aimed at minimizing the risks.

The most important stage in the development of effective strategy of development of the industry is quantitative risk analysis, which enables to give a real assessment of their own resources and capabilities in relation to the state (and needs) the external environment. On this base it should be the rational choice of strategies from a variety of options. 


\section{Conclusions}

The providing the territory with transport is an integral characteristic of its level of development, the most important condition of formation of competitive advantages and investment attractiveness. The risk in the transport sector is both sectoral and territorial in nature and represents the probability of deviations of the results of activity of subjects of a transport complex from the predicted values due to the changes in the economic situation in the transport sector and the socio-economic situation.

The classification of risk factors enables to identify the classification groups that allows to identify them precisely and develop anti-risk events correctly.

During the research, the system of 63 risk indicators (local factors) has been established. In the next stage, each of 63 indicators has been analyzed using the developed technique of the expert assessment of their impact on the functioning of the regional transport systems. The method of rank estimation has been applied for these purposes.

Identification of risks at the national and regional transport systems is necessary for the effective strategy of the industry development through quantitative risk analysis, which enables to give a real assessment of their own resources and capabilities in relation to the state (and needs) of the external environment. The rational choice of the strategies from a variety of options should be made on this basis.

\section{References}

1. K. A. Andriushchenko. Derzhavne upravlinnia: udoskonalennia ta rozvytok. http://www.dy.nayka.com.ua/?op=1\&z=379 (2012)

2. M. N. Bidniak. Production systems on a transport: theory and practice: monograph. Laborator practical work, (2006)

3. O.V. Boiko, I.V. Didovets. Potentsial rynku transportnykh posluh yak ob’iekt naukovykh doslidzhen. http://www.nbuv.gov.ua/portal/Soc_Gum/Vcndtu/ 2010_41/13.htm.(2010)

4. P. F. Gorbachev, I. A.Dmitriev. Osnovy teorii transportnyh sistem. Izd-vo HNADU, Kharkiv, (2002)

5. A. Je. Gorev. Osnovy teorii transportnyh sistem. SPbGASU, SPb., (2010)

6. V.L.Dykan, M.V. Korin. Visnyk ekonomiky transportu i promyslovosti, (33), 13-19 (2011)

7. O. P. Kravchenko, Ye. P. Medvediev. Avtomobil i elektronika. Suchasni tekhnolohii, (4), 48-52 (2013)

8. O. B. Pikulik. Wide choice of Sciences. вісн. Well. National Un th. Lesya Ukrainka, 7, 284-291 (2008)

9. Y. S. Rogozyan. Bulletin of the Eastern Ukrainian University named after V. Dahl, 9(163), 169-173 (2011)

10. A.Balducci, L.Boelens, J.Hillier, T.Nyseth, C.Wilkinson, Transportation planning and policy in the pursuit of mega-events: Boston's 2024 Olympic bid Kassens-Noor. ETransport Policy, 74, 239-245 (2019), doi: 10.1016/j.tranpol.2018.12.005

11. Otto, A., Kellermann P., Thieken A., Máñez Costa M. Carmona, M. Bubeck P. International Journal of Disaster Risk Reduction, 33， 385-397 (2019), doi: $10.1016 /$ j.ijdrr.2018.10.025

12. O.L.Vasyliev, O.M. Lukianova. Visnyk ekonomiky transportu i promyslovosti, 41, 92-95 (2013)

13. A. I. Orlov Prikladnaja statistika. http://www.merriam-webster.com/dictionary/risk (2006).

14. O. Avci, O. Ozbulut. Case Studies on Transport Policy. 6, 4, 663-673 (2018) 
15. Official website of "Transport" journal http://transport-journal.com/about/

16. Official website of RA "Ekspert-Rating” http://www.expert-rating.com

17. N. M. Bogdan. Modeliuvannia regionalnoi ekonomiky. 2(28), 36-51, (2016) 